\begin{tabular}{|c|l|}
\hline Title & $\begin{array}{l}\text { Hydroxyl radical-induced photochemical formation of dicarboxylic acids from unsaturated fatty acid (oleic acid) in } \\
\text { aqueous solution }\end{array}$ \\
\hline Author(s) & Tedetti, Marc; Kawamura, Kimitaka; Narukawa, Masahiro; Joux, Fabien; Charrière, Bruno; Sempéré, Richard \\
\hline Citation & $\begin{array}{l}\text { Journal of Photochemistry and Photobiology A Chemistry, 188(1), 135-139 } \\
\text { https://doi.org/10.1016/.jphotochem.2006.11.029 }\end{array}$ \\
\hline Issue Date & 2007-04 30 \\
\hline Doc URL & http://hdl.handle.net/2115/26169 \\
\hline Type & article (author version) \\
\hline File Information & JPPA 188 1.pdf \\
\hline
\end{tabular}

Instructions for use 


\section{Hydroxyl radical-induced photochemical formation of dicarboxylic acids from unsaturated fatty acid (oleic acid) in aqueous solution}

Marc Tedetti $^{\mathrm{a}}$, Kimitaka Kawamura ${ }^{\mathrm{b}}$, Masahiro Narukawa ${ }^{\mathrm{b}, 1}$, Fabien Joux ${ }^{\mathrm{c}}$, Bruno Charrière ${ }^{\mathrm{a}}$, and Richard Sempéréa, ${ }^{\text {,* }}$

${ }^{a}$ Laboratoire de Microbiologie Géochimie et Ecologie Marines (LMGEM), CNRS/INSU, UMR 6117, Centre d'Océanologie de Marseille, Université de la Méditerranée, Campus de Luminy, Case 901, F-13 288 Marseille Cedex 9, France tedetti@com.univ-mrs; charriere@com.univ-mrs.fr

${ }^{\mathrm{b}}$ Institute of Low Temperature Science, Hokkaido University, N19 W8, Kita-ku, Sapporo 060-0819, Japan kawamura@lowtem.hokudai.ac.jp; narukawa@stelab.nagoya-u.ac.jp

${ }^{\mathrm{c}}$ Université Pierre et Marie Curie-Paris-6, UMR 7621, F 66650 Banyuls-sur-mer, France ; CNRS, UMR 7621, F 66650 Banyuls-sur-mer, France joux@obs-banyuls.fr

* Corresponding author: sempere@com.univ-mrs.fr; Phone: 33 (0)4 918292 12; Fax: $33(0) 491829641$

\footnotetext{
${ }^{1}$ Present address: Solar-Terrestrial Environment Laboratory, Nagoya University, Aichi, Japan
} 


\section{Abstract}

In this study, we assess under laboratory controlled conditions the direct and hydroxyl radical $(\mathrm{OH})$-induced photochemical production of low molecular weight (LMW) dicarboxylic acids and related compounds $\left(\mathrm{C}_{2}-\mathrm{C}_{9}\right)$ (DCAs) from oleic acid (cis-9-octadecenoic, $\left.9 \mathrm{C}_{18}\right)$ in aqueous solution. Nitrate $\left(\mathrm{NO}_{3}^{-}\right)$-amended and unamended oleate solutions were irradiated under ultraviolet-B radiation (UV-B, $313 \mathrm{~nm}$ ) for $5 \mathrm{~h}$, with $\mathrm{NO}_{3}^{-}$being the source of $\mathrm{OH}$. The OH-induced photochemical production of DCAs $\left(\mathrm{C}_{2 \mathrm{di}}-\mathrm{C}_{9 \mathrm{di}}\right)\left(165 \pm 32 \mathrm{nM} \mathrm{h}^{-1}\right)$ was much higher than that induced by the direct effect of UV-B $\left(33 \pm 31 \mathrm{nM} \mathrm{h}^{-1}\right)$, accounting for $85 \%$ of the total (direct $+\mathrm{OH}$-induced) photochemical production of DCAs $\left(\mathrm{C}_{2 \mathrm{di}}-\mathrm{C}_{9 \mathrm{di}}\right)\left(194 \pm 6 \mathrm{nM} \mathrm{h}^{-}\right.$ $\left.{ }^{1}\right)$. Azelaic acid $\left(\mathrm{C}_{9 \mathrm{di}}\right)$ was the dominant photoproduct (comprising 63 and $44 \%$ of DCAs in the direct and $\mathrm{OH}$-induced photochemical production, respectively) followed by $\mathrm{C}_{8 \mathrm{di}}, \mathrm{C}_{7 \mathrm{di}}$ and $\mathrm{C}_{6 \mathrm{di}}$, whereas shorter chain compounds $\left(\mathrm{C}_{2 \mathrm{di}}-\mathrm{C}_{5 \mathrm{di}}\right)$ were minor produced species. Using our estimate of $\mathrm{OH}$ photoproduction $\left(\mathrm{P}-\mathrm{OH}\right.$ in $\left.\mathrm{nM} \mathrm{h}^{-1}\right)$, the production of $\mathrm{C}_{9 \mathrm{di}}$ from $50 \mu \mathrm{M}$ of oleic acid was evaluated to $\sim 36 \mathrm{nM}(\mathrm{nM} \mathrm{OH})^{-1}$. We propose in this work a chemical mechanism for the reaction of $\mathrm{OH}$ with oleic acid in aqueous solution from the cleavage of its double bond, and the subsequent formation of DCAs through oxidation and decarboxylation processes.

Keywords: Oleic acid; dicarboxylic acids; hydroxyl radical; nitrate; UV-B radiation 


\section{Introduction}

Low molecular weight (LMW) dicarboxylic acids and related compounds $\left(\mathrm{C}_{2}-\mathrm{C}_{9}\right)$ (DCAs) are ubiquitous water soluble organic compounds that have been detected in a variety of environmental samples including atmospheric aerosols [1], rain waters [2], ice cores [3], marine sediments [4], fresh waters [5] and seawater [6]. Because of their hygroscopic properties, DCAs can act as cloud condensation nuclei and have an impact on the radiative forcing at the Earth's surface [7]. In atmospheric aerosols, one of the major sources of DCAs is direct and sensitized photooxidation of unsaturated hydrocarbons and fatty acids $[8,9,10]$. Sensitized photooxidation is initiated by powerful oxidizing agents such as ozone $\left(\mathrm{O}_{3}\right)$, hydroxyl radical $(\mathrm{OH})$ and nitrate radical $\left(\mathrm{NO}_{3}\right)$, which are produced by the interactions between ultraviolet-B radiation (UV-B: $280-315 \mathrm{~nm}$ ) and volatile organic compounds and nitrogen oxides.

The reaction of oleic acid (cis-9-octadecenoic, $9 \mathrm{C}_{18}$ ) with $\mathrm{O}_{3}, \mathrm{OH}$ and $\mathrm{NO}_{3}$ has recently emerged as a model system to better understand the photooxidation processes affecting unsaturated fatty acids in atmospheric aerosols $[11,12]$. Oleic acid is degraded through an oxidative cleavage of its double bond to produce $\mathrm{C}_{9}$ compounds, i.e., nonanoic $\left(\mathrm{C}_{9}\right)$, 9-oxononanoic $\left(\omega \mathrm{C}_{9}\right)$ azelaic $\left(\mathrm{C}_{9 \mathrm{di}}\right)$ acids and 1-nonanal $\left(\mathrm{C}_{9 \mathrm{ald}}\right)[13,14,15,16]$ as well as nitrated carboxylic acids [12]. Secondary photooxidation reactions could initiate the production of lower molecular weight DCAs such as $\mathrm{C}_{2 \mathrm{di}}-\mathrm{C}_{8 \mathrm{di}}[9,17,18]$. Although the production of DCAs from photooxidation of unsaturated fatty acids has been largely studied in the atmospheric aerosols, little is known about the direct and sensitized photoproduction of DCAs in aqueous solutions. In seawater, it has been shown that oleic acid, which is produced by phytoplankton [19], was directly photooxidized to produce $\omega \mathrm{C}_{9}$ and $\mathrm{C}_{9 \text { ald }}$ [20]. However, there is no report of concentrations of a homologous series of DCAs from these 
photooxidation processes. In natural waters, many photochemical reactions are driven by $\mathrm{OH}$, which is one of the most reactive oxidants $(E=+1.83 \mathrm{~V})[21,22,23]$. Major sources of $\mathrm{OH}$ in natural waters are the nitrate $\left(\mathrm{NO}_{3}^{-}\right)$and nitrite $\left(\mathrm{NO}_{2}^{-}\right)$photolysis, initiated by UV-B and UVA (315-400 nm), respectively, as well as the photolysis of colored dissolved organic matter (CDOM), initiated by both UV-B and UV-A $[24,25,26]$. Photochemical oxidation reactions may substantially modify molecular distribution and bacterial availability of dissolved organic compounds in natural waters and then play a significant role in aquatic carbon cycle [27,28].

The objective of this study is to assess under laboratory controlled conditions the direct and $\mathrm{OH}$-induced photochemical production of DCAs from oleic acid in aqueous solution (pure water). $\mathrm{NO}_{3}^{-}$was chosen as photosensitizer and source of $\mathrm{OH}$ radicals since (i) quantum yield of $\mathrm{OH}$ formation $\left(\Phi_{\mathrm{OH}}\right)$ from $\mathrm{NO}_{3}{ }^{-}$photolysis is well known $[25,26,29]$, (ii) $\mathrm{NO}_{3}^{-}$is very poor $\mathrm{OH}$ scavenger $\left(\mathrm{k}<1.10^{5} \mathrm{~s}^{-1}\right)$ compared to $\mathrm{NO}_{2}^{-}\left(\mathrm{k}=1.10^{10} \mathrm{~s}^{-1}\right)$ in aqueous solutions [25] and (iii) in natural waters $\mathrm{NO}_{3}{ }^{-}$is often found in much higher concentrations than $\mathrm{NO}_{2}^{-}$. The production of $\mathrm{OH}$ from the UV-B photolysis of $\mathrm{NO}_{3}^{-}$is described by the equations [30,31]:

$$
\begin{aligned}
& {\left[\mathrm{NO}_{3}^{-}+U V-B \rightarrow \mathrm{NO}_{3}^{-}\right]^{*}} \\
& {\left[\mathrm{NO}_{3}^{-}\right]^{*} \rightarrow \mathrm{NO}_{2}+\mathrm{O}^{-}} \\
& \mathrm{O}^{-}+\mathrm{H}_{2} \mathrm{O} \rightarrow \mathrm{OH}+\mathrm{OH}^{-}
\end{aligned}
$$




\section{Materials and methods}

\subsection{Irradiation experiment}

Sodium oleate (99\% purity, Sigma, $50 \mu \mathrm{M}$ final concentration) was added to $0.2-\mu \mathrm{m}$ filtered Milli-Q water (final resistivity $>18 \mathrm{M} \Omega \mathrm{cm}^{-1}$ ). The $\mathrm{pH}$ of Milli-Q water was 6 before adding oleate and 7.6 after the dissolution. To stimulate the production of $\mathrm{OH}$, a subsample of the oleate solution was amended with $\mathrm{NO}_{3}^{-}$(Fluka, $15 \mu \mathrm{M}$ final concentration). The $\mathrm{NO}_{3}^{-}-$ amended and unamended oleate solutions were then dispensed into precombusted $\left(450^{\circ} \mathrm{C}\right.$ for $6 \mathrm{~h})$ quartz and glass (Pyrex) tubes (100 ml volume) that were sealed with ultraclean (extensively rinsed with $1 \mathrm{~N} \mathrm{HCl}$ and Milli-Q water) silicone stoppers wrapped in Teflon foil. The tubes were irradiated for $5 \mathrm{~h}$ under two UV-B fluorescent lamps emitting mainly at 313 $\mathrm{nm}(\mathrm{Q}-\mathrm{Panel} \mathrm{UVB}-313,40 \mathrm{~W})$ at controlled room temperature $\left(15 \pm 1^{\circ} \mathrm{C}\right)$. Quartz tubes, which were used for the UV-B condition, were wrapped in $95 \mu \mathrm{m}$ cellulose diacetate filter to remove residual UV-C (200-280 nm) of the lamps (Fig. 1). Pyrex tubes were wrapped in aluminum foil for the dark controls. Duplicate samples were exposed for each light $/ \mathrm{NO}_{3}{ }^{-}$ treatment. Subsamples for DCA analysis were collected before (T0) and after (T5) 5-h irradiation and stored in $250-\mathrm{ml}$ precombusted glass bottles poisoned with $\mathrm{HgCl}_{2}\left(10 \mathrm{mg} \mathrm{l}^{-1}\right.$ final concentration) at $4^{\circ} \mathrm{C}$ in the dark until measurements.

Irradiance of the UV-B lamps was measured with a IL-1700 broadband radiometer (International Light) equipped with a UV-B probe (SUD240, International Light) covered by cellulose diacetate filter. Irradiance received by the samples was controlled by the distance between lamps and tubes. It was fixed at $4.10^{-5} \mathrm{~W} \mathrm{~cm}^{-2}$, which approximately corresponds to a natural UV-B irradiance at solar noon in summer in mid-latitudes. Irradiance integrated over 5-h irradiation was $7.4510^{-1} \mathrm{~J} \mathrm{~cm}^{-2}$. 


\subsection{Measurement of dicarboxylic acids and related compounds}

DCAs were measured by gas chromatography and flame ionization detection (GC/FID) after butyl ester derivatization [32]. The sample $(50 \mathrm{ml})$ was first concentrated down to 3-4 $\mathrm{ml}$ using a rotary evaporator under a vacuum, then transferred into a $25 \mathrm{ml}$ pear-shaped flask, further concentrated by the rotary evaporator and finally concentrated to almost dryness under a nitrogen stream. A total of $0.25 \mathrm{ml}$ of $14 \% \mathrm{BF}_{3} / \mathrm{n}$-butanol was immediately added to the sample and the flask was sealed with a glass stopper, Teflon tape and clamp. The organic acids and reagent were mixed under ultrasonication for $1 \mathrm{~min}$ and then heated at $100^{\circ} \mathrm{C}$ for 30 min to derive dibutyl esters for carboxyl group and dibutoxy acetal for aldehyde group. The derivatives were extracted with $5 \mathrm{ml}$ of $n$-hexane after adding $3 \mathrm{ml}$ of Milli-Q water and 0.2 $\mathrm{ml}$ of acetonitrile. The hexane layer was further washed with Milli-Q water $(3 \times 3 \mathrm{ml})$. The esters were dried by using a rotary evaporator, then a nitrogen stream and were finally dissolved in $100 \mu 1$ of $n$-hexane prior to GC/FID determination. The dibutyl esters were determined with a Hewlett Packard 5890 gas chromatograph equipped with a split/splitless injector, a fused silica capillary column (HP-5, $25 \mathrm{~m} \times 0.32 \mathrm{~mm} \times 0.52 \mu \mathrm{m})$ and an FID detector. Peak identification was performed by a comparison of GC retention times with those of dibutyl ester standards.

\subsection{Assessment of $\mathrm{OH}$ photoproduction}

$\mathrm{OH}$ photoproduction $(\mathrm{P}-\mathrm{OH})$ from the UV-B irradiation of $15 \mu \mathrm{M} \mathrm{NO}_{3}{ }^{-}$was assessed using the following photochemical equation:

$$
\mathrm{P}-\mathrm{OH}(313)=\mathrm{E}_{0}(313) \times \mathrm{a}(313) \times \Phi_{\mathrm{OH}}(313)
$$

Where $\mathrm{P}-\mathrm{OH}(313)$ is production of $\mathrm{OH}$ at $313 \mathrm{~nm}\left(\right.$ in $\left.\mathrm{nM} \mathrm{h}^{-1}\right), \mathrm{E}_{0}(313)$ is irradiance received by the samples at $313 \mathrm{~nm}\left(4.10^{-5} \mathrm{~W} \mathrm{~cm}^{-2}\right.$ which corresponds to $0.0072 \mathrm{~mol}$ photon $\left.\mathrm{m}^{-2} \mathrm{~h}^{-1}\right)$, $\mathrm{a}(313)$ is absorption coefficient of $15 \mu \mathrm{M} \mathrm{NO}_{3}{ }^{-}$at $313 \mathrm{~nm}\left(0.027 \mathrm{~m}^{-1}\right.$; Fig. 2) and $\Phi_{\mathrm{OH}}(313)$ is quantum yield of $\mathrm{OH}$ formation from $\mathrm{NO}_{3}{ }^{-}$photolysis at $313 \mathrm{~nm}$ used from [29] (1.3\% at 
$20^{\circ} \mathrm{C}$ and $\left.\mathrm{pH} 6.2-8.2\right)$ that we corrected by temperature effect according to the following formula [33]:

$$
\Phi_{\mathrm{OH}}(288 \mathrm{~K})=\Phi_{\mathrm{OH}}(298 \mathrm{~K}) \exp [(1800 \pm 480)(1 / 298-1 / 288)]
$$

The value of $\Phi_{\mathrm{OH}}(313)$ we used for $15^{\circ} \mathrm{C}$ was $1.05 \%$. Consequently, $\mathrm{P}-\mathrm{OH}$ in the $\mathrm{NO}_{3}^{-}-$ amended oleate solutions exposed to UV-B was estimated to be $\sim 2 \mathrm{nM} \mathrm{h}^{-1}$.

\section{Results and Discussion}

Table 1 presents the concentrations of DCAs $\left(\mathrm{C}_{2 \mathrm{di}}-\mathrm{C}_{9 \mathrm{di}}, \omega \mathrm{C}_{9}\right)$ detected in the oleate solutions before and after 5-h irradiation. We observed that the total concentration of DCAs after irradiation under UV-B in the presence of $\mathrm{NO}_{3}{ }^{-}\left(\mathrm{T} 5 \mathrm{UV}-\mathrm{B}+\mathrm{NO}_{3}{ }^{-}\right)(1140 \pm 30 \mathrm{nM})$ was much higher than that under UV-B alone (T5 UV-B) (314 $\pm 156 \mathrm{nM})$ (Table 1). 9oxononanoic acid $\left(\omega \mathrm{C}_{9}\right)$ was not detected in the different samples, whereas azelaic acid $\left(\mathrm{C}_{9 \mathrm{di}}\right)$ was found as the dominant species, accounting for $\sim 36 \%$ and $42 \%$ of the total DCA concentration in conditions T5 UV-B and T5 UV-B $+\mathrm{NO}_{3}{ }^{-}$, respectively (Table 1). These concentrations are closed to that found recently in Mediterranean surface seawater samples $(700-730 \mathrm{nM})[6]$.

In order to evaluate the photochemical production of DCAs (in $\mathrm{nM} \mathrm{h}^{-1}$ ) from the 5-h irradiation of oleic acid, the concentrations reported in Table 1 for UV-B conditions were corrected for the corresponding "dark" and then divided by a factor 5. Direct (UV-B-induced), $\mathrm{OH}$-induced and total (direct $+\mathrm{OH}$-induced) photochemical productions of DCA were determined by subtracting the DCA concentration in UV-B by that in dark ([DCA $]_{\mathrm{T} 5 \mathrm{UV}-\mathrm{B}}$ $\left.[D C A]_{T 5 \text { dark }}\right)$, the DCA concentration in UV-B $+\mathrm{NO}_{3}{ }^{-}$by that in UV-B $\left([\mathrm{DCA}]_{\mathrm{T} 5 \mathrm{UV}-\mathrm{B}+\mathrm{NO}-{ }_{-}}{ }^{-}\right.$ $\left.[D C A]_{\mathrm{T} 5} \mathrm{UV}_{-\mathrm{B}}\right)$ and the DCA concentration in UV-B $+\mathrm{NO}_{3}{ }^{-}$by that in dark $+\mathrm{NO}_{3}{ }^{-}\left([\mathrm{DCA}]_{\mathrm{T} 5}\right.$

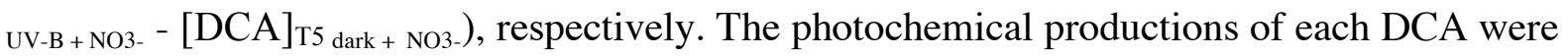
then summing to obtain the photochemical production of total DCAs $\left(\mathrm{C}_{2 \mathrm{di}}-\mathrm{C}_{9 \mathrm{di}}\right)$ (Fig. 3). 
Clearly, the $\mathrm{OH}$-induced photochemical production of DCAs $\left(165 \pm 32 \mathrm{nM} \mathrm{h}^{-1}\right)$ was much higher than that induced by the direct effect of UV-B $\left(33 \pm 31 \mathrm{nM} \mathrm{h}^{-1}\right)$, accounting for $85 \%$ of the total (direct + OH-induced) photochemical production of DCAs $\left(194 \pm 6 \mathrm{nM} \mathrm{h}^{-1}\right)$ (Fig. 3). Consequently, the UV-B photolysis of $\mathrm{NO}_{3}{ }^{-}$and the subsequent production of $\mathrm{OH}(\mathrm{P}-\mathrm{OH} \sim 2$ $\mathrm{nM} \mathrm{h}^{-1}$ ) and its reaction with oleic acid is much more efficient in producing DCAs (from $\mathrm{C}_{9 \mathrm{di}}$ to $\mathrm{C}_{2 \mathrm{di}}$ ) than the direct effect of UV-B on oleic acid, the latter leading only to the production of DCAs from $\mathrm{C}_{9 \mathrm{di}}$ to $\mathrm{C}_{7 \mathrm{di}}$ (Fig. 3). $\mathrm{C}_{9 \mathrm{di}}$ was the dominant photoproduct (comprising 63 and $44 \%$ of DCAs in the direct and $\mathrm{OH}-$ induced photochemical production, respectively) followed by $\mathrm{C}_{8 \mathrm{di}}, \mathrm{C}_{7 \mathrm{di}}$ and $\mathrm{C}_{6 \mathrm{di}}$, whereas shorter chain compounds $\left(\mathrm{C}_{2 \mathrm{di}}-\mathrm{C}_{5 \mathrm{di}}\right)$ were minor species ( $\mathrm{OH}$-induced production) or not detected as photoproducts (direct production) (Fig. 3). The $\mathrm{OH}$-induced photochemical degradation of oleic acid led to a $\mathrm{C}_{9 \mathrm{di}}$ production of $72 \pm$ $16 \mathrm{nM} \mathrm{h}^{-1}$ (Fig. 3). Therefore, using our P-OH calculated value of $2 \mathrm{nM} \mathrm{h}^{-1}$, the production of $\mathrm{C}_{9 \mathrm{di}}$ from $50 \mu \mathrm{M}$ of oleic acid in aqueous solution can be assessed to $\sim 36 \mathrm{nM}(\mathrm{nM} \text { OH })^{-1}$. The total photochemical production of DCAs $\left(\mathrm{C}_{2 \mathrm{di}}-\mathrm{C}_{9 \mathrm{di}}\right)$ for 5 -h irradiation $(971 \mathrm{nM})$ represents $7.4 \mu \mathrm{M} \mathrm{C}$ and thus account for $0.8 \%$ of the initial concentration of oleic acid (900 $\mu \mathrm{M}$ C). In addition to DCAs $\left(\mathrm{C}_{2 \mathrm{di}}-\mathrm{C}_{9 \mathrm{di}}\right)$, many other intermediates and photochemically stable compounds are likely produced from the $\mathrm{OH}$-induced degradation of oleic acid in aqueous solution. For atmospheric aerosols, some authors reported the photoproduction of $\mathrm{C}_{9}, \omega \mathrm{C}_{9}$, $\mathrm{C}_{9 \mathrm{di}}$ and $\mathrm{C}_{9 \mathrm{ald}}$, as well as nitrated carboxylic acids from the reaction of oleic acid with $\mathrm{OH}, \mathrm{O}_{3}$ or $\mathrm{NO}_{3}[12,13,14,15,16]$. In this study, $\mathrm{C}_{9}$ and $\mathrm{C}_{9 \text { ald }}$ could not be determined using our GC/FID technique. However, $\omega \mathrm{C}_{9}$ was found to be below the detection limit in the samples, suggesting that this compound, once produced from oleic acid, was immediately oxidized into $\mathrm{C}_{9 \mathrm{di} \cdot}$.

A chemical mechanism for the reaction of $\mathrm{OH}$ radicals with oleic acid in aqueous solution and the subsequent formation of DCAs $\left(\mathrm{C}_{2 \mathrm{di}}-\mathrm{C}_{9 \mathrm{di}}\right)$ is proposed in Figure 4 . Both the 
action of $\mathrm{OH}$ that is produced by the UV-B photolysis of $\mathrm{NO}_{3}^{-}$, and dissolved oxygen $\left(\mathrm{O}_{2}\right)$ in the aqueous solution, leads to the cleavage of the double bond of oleic acid and to the production of two $\mathrm{C}_{9}$ compounds, i.e., $\omega \mathrm{C}_{9}$ and $\mathrm{C}_{9 \text { ald }}$. From the action of both ${ }^{\bullet} \mathrm{OH}$ and $\mathrm{O}_{2}$, $\omega \mathrm{C}_{9}$ is oxidized into $\mathrm{C}_{9 \mathrm{di}}$. The oxidation of DCAs is assumed occurring via $\mathrm{H}$-atom abstraction by $\mathrm{OH}$ followed by the $\mathrm{O}_{2}$-induced formation of peroxy radical. From $\mathrm{C}_{9 \mathrm{di}}$, other $\mathrm{DCAs}\left(\mathrm{C}_{8 \mathrm{di}}\right.$ to $\mathrm{C}_{2 \mathrm{di}}$ ) are then produced through oxidation and decarboxylation processes involving the formation of hydroxy diacid, keto diacid, wketoacid and diacid $\left(\mathrm{C}_{\mathrm{n}-1 \mathrm{di}}\right)$.

This study clearly shows that $\mathrm{OH}$ efficiently produces DCAs, especially $\mathrm{C}_{9 \mathrm{di}}$, from unsaturated fatty acids in aqueous solution. As regard to the experimental conditions we used, including $\mathrm{pH}$, temperature, irradiance as well as $\mathrm{NO}_{3}{ }^{-}$and oleate concentrations, we can expect to have, qualitatively, similar $\mathrm{C}_{2 \mathrm{di}}-\mathrm{C}_{9 \mathrm{di}}$ photochemical production in various natural waters including fresh, river and rain waters. However, in seawater, $\mathrm{OH}$, which reacts almost exclusively with bromide ion $\left(\mathrm{Br}^{-}\right)$to generate the less reactive dibromide anion $\left(\mathrm{Br}_{2}^{-}\right)$, is unlikely as efficient in degrading unsaturated fatty acids [22,34]. 


\section{Acknowledgments}

We thank K. Okuzawa for his help of data process in the diacid analysis. This study was supported by the CNRS-PROOF UVECO project, the region Provence Alpes Côte d'Azur, the "College Doctoral Franco-Japonais", Airmaraix and also by Japanese Ministry of Education, Culture, Sports, Science, and Technology through grant-in-aid 01470041. 


\section{References}

[1] K.F. Ho, S.C. Lee, J.J. Cao, K. Kawamura, T. Watanabe, Y. Cheng, J.C. Chow, Atmos. Environ. 40 (2006) 3030-3040.

[2] R. Sempéré, K. Kawamura, Atmos. Environ. 30 (1996) 1609-1619.

[3] K. Kawamura, K. Yokoyama, Y. Fujii, O. Watanabe, J. Geophys. Res. 106 (2001) 13311345.

[4] A. Gogou, E.G. Stephanou, Mar. Chem. 85 (2004) 1-25.

[5] T. Brinkmann, P. Hörsch, D. Sartorius, F.H. Frimmel, Sci. Technol. 37 (2003) 4190-4198.

[6] M. Tedetti, K. Kawamura, B. Charrière, N. Chevalier, R. Sempéré, Anal. Chem. 78 (2006) $6012-6018$

[7] V.-M. Kerminen, C. Ojanen, T. Pakkanen, R. Hillamo, M. Aurela, J. Merilainen, J. Aerosol Sci. 31 (2000) 349-362.

[8] K. Kawamura, R. Sempéré, Y. Imai, J. Geophys. Res. 101 (1996) 18,721-18,72

[9] R. Sempéré, K. Kawamura, Global Biogeochem. Cycles. 17 (2003) 38,1-38,15.

[10] K. Kawamura, Y. Imai, L.A. Barrie, Atmos. Environ. 39 (2005) 599-614.

[11] H.-M. Hung, Y. Katrib, S.T. Martin, J. Phys. Chem. A. 109 (2005) 4517-4530.

[12] K.S. Docherty, P.J. Ziemann, J. Phys. Chem. A. 110 (2006) 3567-3577.

[13] E.G. Stephanou, N. Stratigakis, Environ. Sci. Technol. 27 (1993) 1403-1407.

[14] Y. Katrib, S.T. Martin, H-M. Hung, Y. Rudich, H. Zhang, J.G. Slowik, P. Davidovits, J.T. Jayne, D.R. Worsnop, J. Phys. Chem. A. 108 (2004) 6686-6695.

[15] J.D. Hearn, G.D. Smith, J. Phys. Chem. A. 108 (2004) 10019-10029.

[16] R.L. Grimm, R. Hodyss, J.L. Beauchamp, Anal. Chem. 78 (2006) 3800-3806.

[17] K. Kawamura, R.B. Gagosian, Nature. 325 (1987) 330-332.

[18] S. Matsunaga, K. Kawamura, T. Nakatsuka, N. Ohkouchi, Res. Org. Geochem. 14 (1999) $19-25$.

[19] P. Gschwend, O.C. Zafiriou, R.B. Gagosian, Limnol. Oceanogr. 25 (1980) 1044-1053. 
[20] R.J. Kieber, L.H. Hydro, P.J. Seaton, Limnol. Oceanogr. 42 (1997) 1454-1462.

[21] Mill, T., 1980. Chemical and photo oxidation, in: O. Hutzinger (Ed.), The Handbook of Environmental Chemistry, Vol 2 Part A. Springer, Berlin, pp. 77-105.

[22] O.C. Zafiriou, J. Joussot-Dubien, R.G. Zepp, R.G. Zika, Environ. Sci. Technol. 18 (1984) 356-371.

[23] X. Zhou, K. Mopper, Mar. Chem. 30 (1990) 71-88.

[24] P.P. Vaughan, N.V. Blough, Environ. Sci. Technol. 32 (1998) 2947-2953.

[25] J. Mack, J.R. Bolton, J. Photochem. Photobiol. A: Chem. 128 (1999) 1-13.

[26] J. Qian, K. Mopper, D.J. Kieber, Deep-Sea Res. I. 48 (2001) 741-759.

[27] K. Mopper, D.J. Kieber, 2000. Marine photochemistry and its impact on carbon cycling, in: S. de Mora, S. Demers, M. Vernet (Eds.), The effects of UV radiation in the marine environment, Cambridge University Press, Cambridge, pp. 101-129.

[28] K. Mopper, D.J. Kieber, 2002. Photochemistry and the cycling of carbon, sulphur, nitrogen and phosphorus, in: D.A. Hansell, C.A. Carlson (Eds.), Biogeochemistry of marine dissolved organic matter, Academic Press, San Diego, pp. 455-507.

[29] R.G. Zepp, J. Hoigné, H. Bader, Environ. Sci. Technol. 21 (1987) 443-450

[30] I. Wagner, H. Strehlow, G. Busse, Z. Phys. Chemie. Neue Folge 123 (1980) 1-33.

[31] A. Alif, P. Boule, J. Photochem. Photobiol. A: Chem. 59 (1991) 357-367.

[32] K. Kawamura, K. Ikushima, Environ. Sci. Technol. 27 (1993) 2227-2235.

[33] H. Akimoto, H. Takagi, F. Sakamaki, Int. J. Chem. Kinet. 13 (1981) 735-738.

[34] R.-C. Bouillon, W.L. Miller, Environ. Sci. Technol. 39 (2005) 9471-9477. 


\section{Figure legends}

Figure 1. Transmittance of light via cellulose diacetate filter.

Figure 2. UV absorption spectrum of $15 \mu \mathrm{M} \mathrm{NO}_{3}{ }^{-}$in Milli-Q water measured using a Shimadzu UV-1605 spectrophotometer equipped with a 10-cm quartz cuvette.

Figure 3. Direct $\left([\mathrm{DCA}]_{\mathrm{T} 5 \mathrm{UV}-\mathrm{B}}-[\mathrm{DCA}]_{\mathrm{T} 5 \text { dark }}\right), \mathrm{OH}-\mathrm{induced}\left([\mathrm{DCA}]_{\mathrm{T} 5} \mathrm{Uv-B}+\mathrm{NO}_{-}-{ }[\mathrm{DCA}]_{\mathrm{T} 5} \mathrm{UV}-\right.$ $\left.{ }_{\mathrm{B}}\right)$ and total (direct $+\mathrm{OH}-$ induced $)\left([\mathrm{DCA}]_{\mathrm{T} 5 \mathrm{UV}-\mathrm{B}+\mathrm{NO}_{-}-}-[\mathrm{DCA}]_{\mathrm{T} 5 \text { dark }+ \text { NO3-}}\right)$ photochemical production of DCAs $\left(\mathrm{C}_{2 \mathrm{di}}-\mathrm{C}_{9 \mathrm{di}}\right)\left(\right.$ in $\left.\mathrm{nM} \mathrm{h}^{-1}\right)$ from UV-B irradiation of $50 \mu \mathrm{M}$ oleic acid in aqueous solution.

Figure 4. Proposed chemical mechanism for the reaction of $\mathrm{OH}$ with oleic acid in aqueous solution and the subsequent formation of DCAs $\left(\mathrm{C}_{2 \mathrm{di}}-\mathrm{C}_{9 \mathrm{di}}\right)$ through oxidation and decarboxylation processes. 
Table I. Concentrations (in $\mathrm{nM}$ ) of dicarboxylic acids $\left(\mathrm{C}_{2 \mathrm{di}}-\mathrm{C}_{9 \mathrm{di}}\right)$ and oxocarboxylic acid $\left(\omega \mathrm{C}_{9}\right)$ in the $\mathrm{NO}_{3}^{-}$-amended and unamended oleate solutions before (T0) and after (T5) 5-h irradiation under UV-B lamps or in the dark.

\begin{tabular}{|c|c|c|c|c|c|c|}
\hline compounds & T0 & $\begin{aligned} & \mathrm{T} 0 \\
&+\mathrm{NO}_{3}^{-}\end{aligned}$ & T5 dark & $\begin{array}{l}\text { T5 dark } \\
+\mathrm{NO}_{3}^{-}\end{array}$ & T5 UV-B & $\begin{array}{l}\text { T5 UV-B } \\
+\mathrm{NO}_{3}^{-}\end{array}$ \\
\hline oxalic acid, $\mathrm{C}_{2 \mathrm{di}}$ & 25 & 41 & $33 \pm 15$ & $27 \pm 6$ & $23 \pm 7$ & $60 \pm 5$ \\
\hline malonic acid, $\mathrm{C}_{3 \mathrm{di}}$ & 14 & 9 & $18 \pm 21$ & $8 \pm 4$ & $5 \pm 1$ & $39 \pm 1$ \\
\hline succinic acid, $\mathrm{C}_{4 \mathrm{di}}$ & 14 & 11 & $7 \pm 0$ & $10 \pm 0$ & $8 \pm 1$ & $31 \pm 7$ \\
\hline glutaric acid, $\mathrm{C}_{5 \mathrm{di}}$ & 10 & 2 & $2 \pm 2$ & $3 \pm 4$ & $2 \pm 1$ & $24 \pm 35$ \\
\hline adipic acid, $\mathrm{C}_{6 \mathrm{di}}$ & 116 & 102 & $97 \pm 4$ & $92 \pm 6$ & $72 \pm 14$ & $198 \pm 38$ \\
\hline pimelic acid, $\mathrm{C}_{7 \mathrm{di}}$ & 30 & 22 & $10 \pm 8$ & $6 \pm 4$ & $27 \pm 32$ & $156 \pm 42$ \\
\hline suberic acid, $\mathrm{C}_{8 \mathrm{di}}$ & 31 & 25 & $21 \pm 20$ & $9 \pm 6$ & $63 \pm 68$ & $156 \pm 30$ \\
\hline azelaic acid, $\mathrm{C}_{9 \mathrm{di}}$ & 37 & 39 & $11 \pm 2$ & $14 \pm 1$ & $114 \pm 75$ & $476 \pm 30$ \\
\hline $\begin{array}{l}\text { 9-oxononanoic, } \\
\omega \mathrm{C}_{9}\end{array}$ & 0 & 0 & 0 & 0 & 0 & 0 \\
\hline Total & 277 & 251 & $199 \pm 7$ & $169 \pm 5$ & $314 \pm 156$ & $1140 \pm 30$ \\
\hline
\end{tabular}

For T5 conditions, averaged concentrations are given with a standard deviation based on duplicate samples exposed in the same light $/ \mathrm{NO}_{3}{ }^{-}$conditions. 


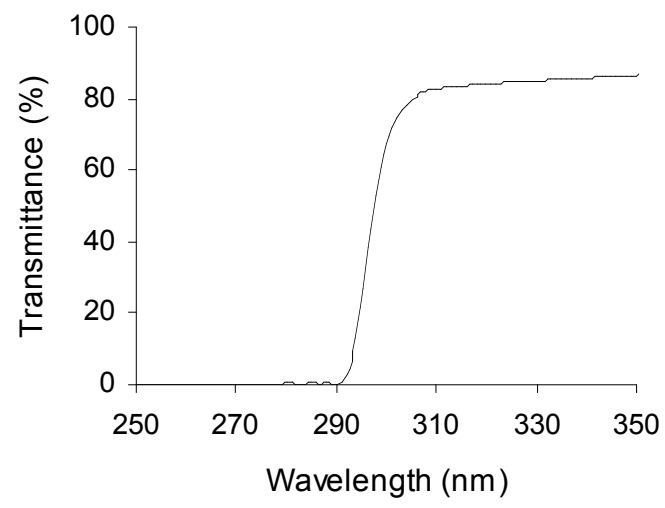

Figure 1 


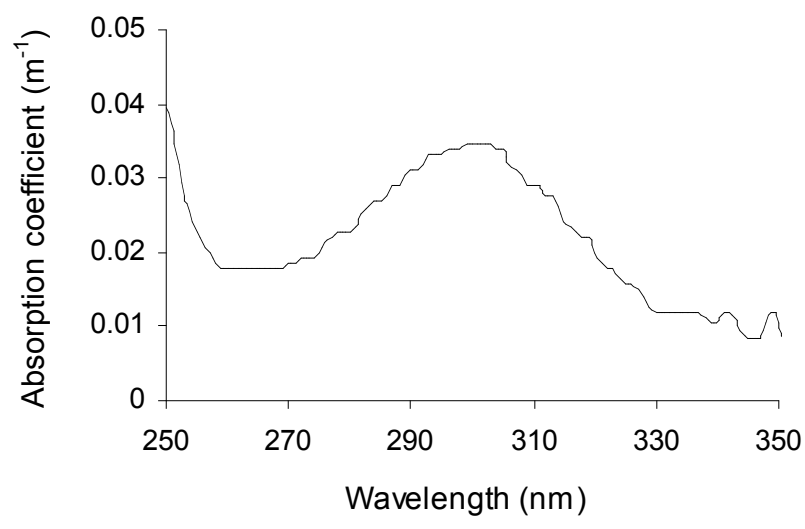

Figure 2 


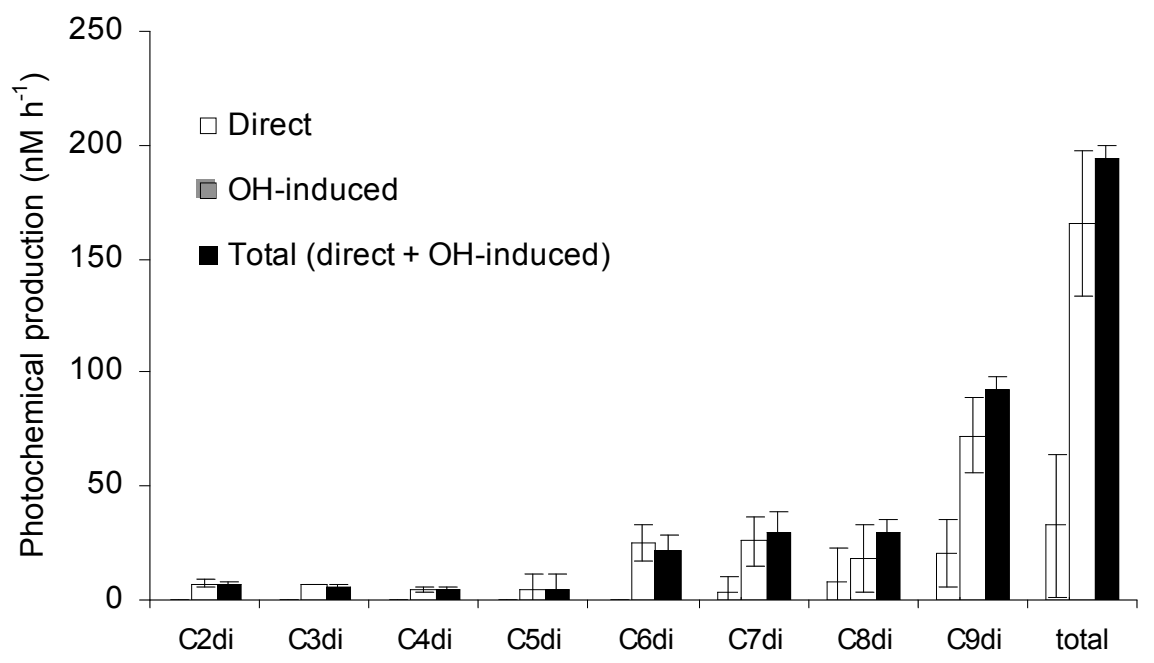

Figure 3 

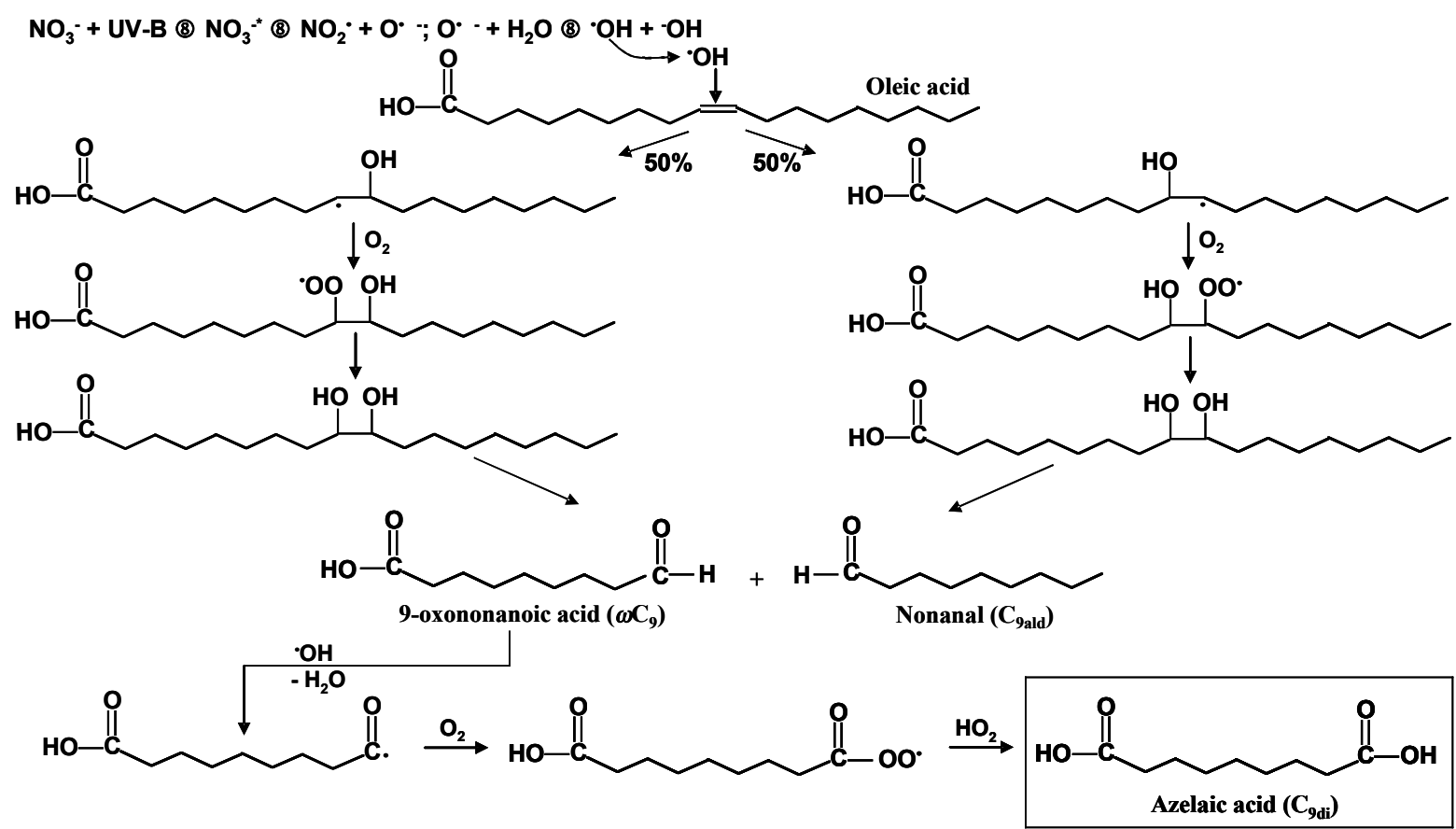

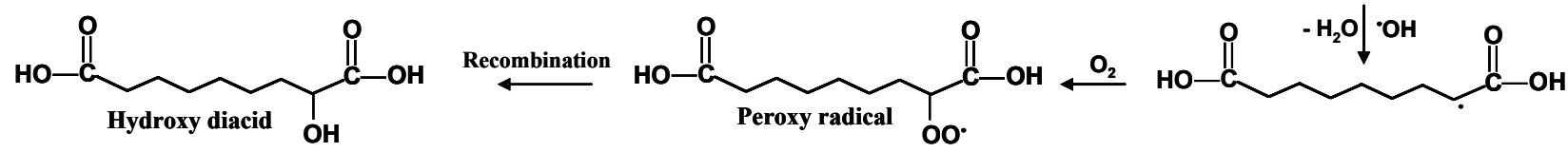

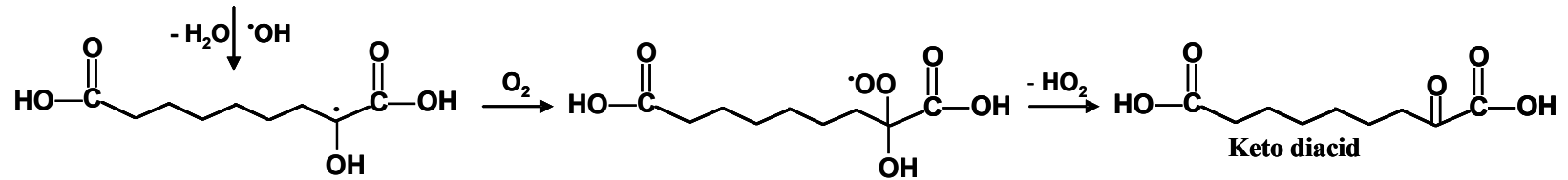

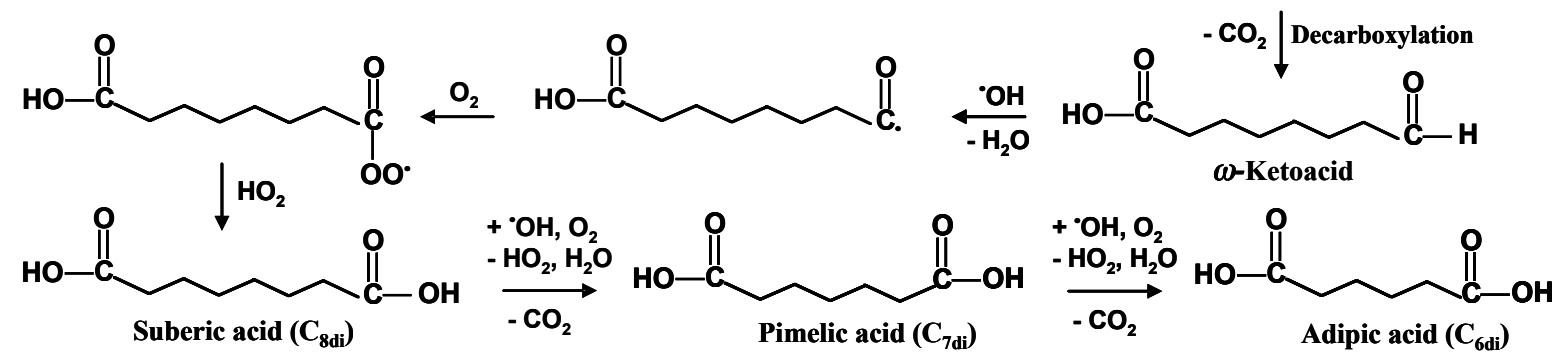

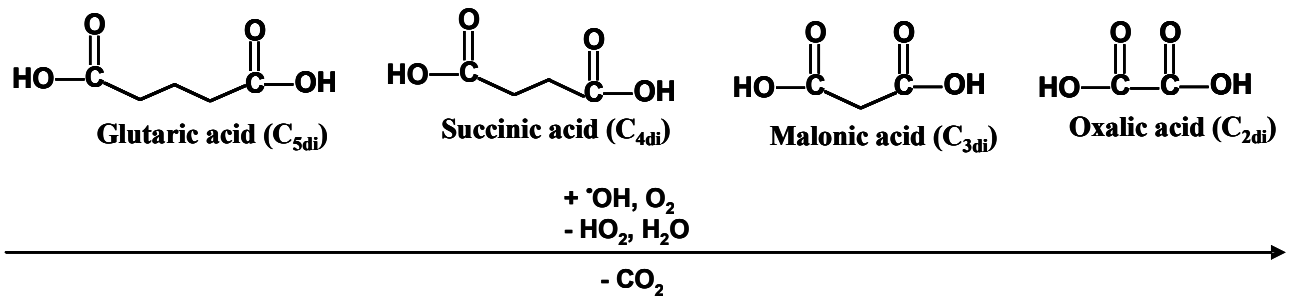

Figure 4 